\title{
Management methods of harmful pests in the cotton-wheat crop rotation system
}

\author{
Botir Boltayev ${ }^{1, *}$ and Sanjar Boltayev ${ }^{1}$ \\ ${ }^{1}$ Tashkent State Agrarian University, Universitetskaya str., 2, 100140, Tashkent, \\ Uzbekistan
}

\begin{abstract}
This article analyzed the ecological succession between pests of crops as a result of the transition from the traditional cotton-alfalfa crop rotation system to the cotton-grain crop rotation system. It was found that the species composition, development and propagation characteristics of harmful organisms in the weeds around the field, as well as in the intermediate crops, can be reduced by up to $60-70 \%$, and protected entomophagous organisms from the destructive effects of pesticides through lateral tillage of the 30 -meter edge of the cotton crop. Furthermore, it was possible to apply biological methods to the remaining $70-80 \%$ of the field. It was necessary to properly organize the system of crop rotation "Cotton-grain" towards naturally controlling (reduce or eliminate) the number of harmful organisms (pests, diseases and weeds) in the agrophytocenosis. It was observed that diseases (especially rust), weeds (especially wild oats, raygras), pests (weeds, wheat thrips, slime,) were 2-3 times less in the grain planted after cotton, the number of spiders in the cotton field planted after grain were 3-4 times less, and diseases were decreased by $25-30 \%$.
\end{abstract}

\section{Introduction}

One of the important factors for obtaining a quality abundant crop from agricultural crops is the protection of crop areas from pests, diseases and weeds. FAO, which deals with agricultural and food issues under the United Nations, stated that $30-35 \%$ of its crop was being killed each year due to pests, diseases and weeds in the world, and in some developing countries, that indicator was exceeded by $50 \%[1-4,13]$. Initially, only the chemical method was used, as it was effective in combating pests. However, in recent years, the emergence of resistant populations of pests in nature under the influence of pesticides and diseases has led to the disruption of the balance of the biological chain, the negative impact on biodiversity, such as a sharp increase in weeds, pests and disease

* Corresponding author:botir.boltayev@yandex.uz 
species $[5-7,12]$. In the system of harmonized protection of cereals and other crops from harmful organisms, the agrotechnical method is the most optimal and harmless for the environment [14]. It was identified that if agrotechnical measures (exchange planting, feeding, timely processing of land, irrigation in moderation, loss of plant residues) was done on time and qualitatively, the chemical method may not be left untouched [10-12]. Without this method, there is no way to get high efficiency from other methods. However, as in all areas, there are problems in this area [7, 14]. Therefore, this research was aimed at developing and implementing innovative resource-saving methods of managing the number of harmful organisms of crops on the basis of a comprehensive survey of the changes taking place in crop rotation entomocenosis.

\section{Materials and methods}

In 2016-2017, research observations were conducted in cotton and grain growing areas (Akdarya, Pastdargam, Payarik, Samarkand, Taylak and Bulungur) of Samarkand province to determine the distribution of entomophagous insects in the agrophytocenosis of cotton and grain, the balance and formation of species in the species. The observation work lasted from the beginning of March to the end of August. Insect migration used pheromone handles and syrup handles as well as new types of insect handles. The collected insects and other pests were carried out on site at the Scientific Research Center for Biological Protection of Plants.

In order to take into account, the entomofauna in cotton-grain agrophytocenosis, common methods of pest and entomophagous weeds in the field around the field were observed from early spring (March) to the formation of leaf litter in cotton and during vegetation in grain fields $[13,14]$. In cotton, 10-20 samples were taken from each field, 510 plants were seen in each sample, and the species composition and quantity of pests and entomophagous species are studied. From entomophagous beetles, golden-eyed, sirfid flies, wild thrips, orius, and nabis shackles were studied in every 100 plants (10 samples). In the study of migrants migrating aphids (plant lice) in the world practice [6] widely used watery yellow dish (yellow water traps) was employed. These pots were placed at a height of 10$15 \mathrm{~cm}$ from the plant. In addition, pheromone traps, light traps, were used to account for pests [3]. Syrup, thrips, and spider mites were studied in 100 plants (20 specimens, 10 plants) and 100 leaves during the developmental stages. [6, 14]. Light traps (BUF-30) and pheromone traps were used to control the flight of flying insects at night. In the field, insect repellent (entomological scales) and a new type of catcher (A.S.№ 1468487) were used to collect insects [8]. Collected insects were brought to the Center for Biological Protection by other pests from the biological microscope (MBS-1), which magnifies their species by 5 , $10,20,40,60$ and 100 times, and by hand magnifiers of different sizes was determined [11$14]$.

\section{Results and discussion}

The transition to the "Cotton-grain" crop rotation system has a positive side; for example, grain monophagous pests: (harmful weeds, wheat thrips, and slime worms) do not harm cotton, which is certainly good, but there are other aspects of the problem [14]. Changes in the agro-phytocenosis were also evident in the farms of Samarkand province. In some grain-growing districts (Samarkand, Taylak, Bulungur) there was a significant increase in single-stage weeds (wild oats, foxtail, raygras) and an increase in their resistance to herbicides, which created new problems for farmers. 
In the cotton-grain rotation system, weeds around the field served as the main source of phytophagous and entomophagous gatherings. Among the main pests of weeds around the grain field were large grain lice (Schis graminium Rond), wheat thrips (Haplothrips tritici Kurd), harmful weeds (Eurogaster integriceps Put,) slimy worm (Lema melonopus L.), Hessen fly (Mayetio), Swedish fly (Oscinella frit L.). The main pests in the weeds around the cotton field were:spider (Tetranychi urticae Koch), cotton (melon) lice (Aphis gossypii Glov.), Tobacco thrips (Thrips tabaci Lind), large cotton lice (Acyrthosiphon gossypia), alfalfa (Adelpocorius lineolatus Goere), field alligator (Lugus gemelatus L.), cotton nightshade (Heliothis armigera Hb.), Autumn nightshade (Agrothis segetum Schiff), potentially dangerous:(Bemisia tabaci Genn), cotton leaf worm (Spodoptera exigua HB.) and others (Table 1). In addition, in the cotton-grain, agrobiocenosis, insectivorous insects were:Asian (locust) locust (Locusta migratoria migratori L), Moroccan locust (Dociastaurus maroccanus T), Italian locust (Calliptamus italicus L.), field chul (Acheta deserta Pull), Bordeaux chrysanthemum (Tartarogryllis Latr.), Turkestan chrysanthemum (Agriotes metuculosus Cand.) and entomophagous:squirrels, golden-eyed, orius and nabis handcuffs, wild thrips, buzzard beetles, sirfid and galitsa flies.

Table 1. Dominant species in the entomofauna of cotton-grain agrophytocenosis in 2017 (Samarkand province, 2016-2018)

\begin{tabular}{|c|c|c|c|c|c|c|}
\hline \multirow{3}{*}{ Category } & \multirow[b]{2}{*}{ Family } & \multirow[b]{2}{*}{ Type } & \multicolumn{2}{|c|}{ Cotton } & \multicolumn{2}{|c|}{ Grain } \\
\hline & & & Crops & $\begin{array}{c}\text { weeds } \\
\text { around } \\
\text { the field }\end{array}$ & Crops & $\begin{array}{c}\text { weeds } \\
\text { around the } \\
\text { field }\end{array}$ \\
\hline & & Phytophagous & & & & \\
\hline \multirow{8}{*}{ Homoptera } & \multirow{7}{*}{ Aphididae } & $\begin{array}{l}\text { Aphis gossypii } \\
\text { Glov }\end{array}$ & +++ & +++ & + & + \\
\hline & & $\begin{array}{l}\text { Acyrthosiphon } \\
\text { gossypii } \\
\text { Mordv } \\
\end{array}$ & ++ & ++ & + & + \\
\hline & & $\begin{array}{c}\text { Aphis } \\
\text { crassivora } \\
\text { medicadinis } \\
\text { Koch }\end{array}$ & +++ & +++ & + & ++ \\
\hline & & $\begin{array}{c}\text { Sitobion } \\
\text { avenae Gabr }\end{array}$ & - & + & ++ & ++ \\
\hline & & $\begin{array}{c}\text { Schizaphis } \\
\text { gramium Rond }\end{array}$ & + & + & ++ & ++ \\
\hline & & $\begin{array}{l}\text { Brachycolus } \\
\text { poxius Mordv. }\end{array}$ & & + & ++ & ++ \\
\hline & & $\begin{array}{l}\text { Rhopalosiphu } \\
\text { m pale L. }\end{array}$ & & + & ++ & ++ \\
\hline & Aleyrodidae & $\begin{array}{c}\text { Bemisia } \\
\text { Tabaci }\end{array}$ & + & + & & \\
\hline \multirow{2}{*}{ Thysanoptera } & \multirow{2}{*}{ Thripidae } & $\begin{array}{c}\text { Thrips tabaci } \\
\text { Lind }\end{array}$ & +++ & +++ & + & + \\
\hline & & $\begin{array}{l}\text { Haplothrips } \\
\text { tritici Kurd }\end{array}$ & + & + & +++ & +++ \\
\hline
\end{tabular}




\begin{tabular}{|c|c|c|c|c|c|c|}
\hline \multirow[t]{4}{*}{ Hemiptera } & \multirow[t]{2}{*}{ Miridae } & $\begin{array}{c}\text { Adelpocorius } \\
\text { Lineolatus } \\
\text { Goere }\end{array}$ & + & ++ & + & ++ \\
\hline & & $\begin{array}{c}\text { Lugus } \\
\text { gemelatus L. }\end{array}$ & + & ++ & + & + \\
\hline & \multirow{2}{*}{ Pentatomidae } & $\begin{array}{c}\text { Eurogaster } \\
\text { integriceps Put }\end{array}$ & & & ++ & + \\
\hline & & $\begin{array}{l}\text { Aetia furcula } \\
\text { F. }\end{array}$ & & & + & + \\
\hline \multirow{4}{*}{ Orthoptera } & \multirow{4}{*}{ Acrididae } & $\begin{array}{c}\text { Locusta } \\
\text { migratoria L }\end{array}$ & + & + & + & + \\
\hline & & $\begin{array}{c}\text { Dociastaurus } \\
\text { maroccanus } \\
\text { Thnd. }\end{array}$ & + & + & + & + \\
\hline & & $\begin{array}{l}\text { Calliptamus } \\
\text { italicus L. }\end{array}$ & + & + & + & + \\
\hline & & $\begin{array}{c}\text { Acheta deserta } \\
\text { Pull. }\end{array}$ & + & + & + & + \\
\hline Coleopterans & Chrysomelidae & $\begin{array}{c}\text { Lema } \\
\text { melonopus L. }\end{array}$ & 0 & + & +++ & ++ \\
\hline \multirow{2}{*}{ Diptera } & Cecidomyiidae & $\begin{array}{c}\text { Mayetiola } \\
\text { destructor Say }\end{array}$ & ++ & ++ & ++ & + \\
\hline & Chloropidae & $\begin{array}{l}\text { Oscinella frit } \\
\text { L. }\end{array}$ & + & + & + & + \\
\hline \multirow{5}{*}{ Lepidoptera } & \multirow{4}{*}{ Noctidae } & $\begin{array}{c}\text { Heliothis } \\
\text { armigera } \mathrm{Hb}\end{array}$ & ++ & + & 0 & + \\
\hline & & $\begin{array}{c}\text { Agrothis } \\
\text { segetum Schiff }\end{array}$ & + & + & + & + \\
\hline & & $\begin{array}{l}\text { Spodoptera } \\
\text { exidia HB. }\end{array}$ & + & + & + & + \\
\hline & & $\begin{array}{c}\text { Ostrima } \\
\text { nibitalis } \mathrm{Hb} .\end{array}$ & + & + & + & + \\
\hline & & Энтомофаглар & & & & \\
\hline \multirow{4}{*}{ Heteroptera } & Nabidae & Nabis ferus L. & + & + & + & + \\
\hline & \multirow{2}{*}{ Antnacoridae } & $\begin{array}{l}\text { Anthocoris } \\
\text { nemorum L. }\end{array}$ & + & + & + & + \\
\hline & & $\begin{array}{c}\text { Orius Niger } \\
\text { Woef. } \\
\text { O.Albidiprenis. } \\
\text { Reut. }\end{array}$ & + & + & + & + \\
\hline & Miridae & $\begin{array}{c}\text { Deraecoris } \\
\text { Punctilatus } \\
\text { Schiff. }\end{array}$ & + & + & + & + \\
\hline
\end{tabular}




\begin{tabular}{|c|c|c|c|c|c|c|}
\hline & & $\begin{array}{l}\text { Campylomma } \\
\text { verbasci M.D. }\end{array}$ & + & + & + & + \\
\hline & & $\begin{array}{l}\text { C.diversicornis } \\
\text { Reut. }\end{array}$ & + & + & + & + \\
\hline \multirow{2}{*}{ Thysanoptera } & & $\begin{array}{l}\text { Scolothrips } \\
\text { acariphagus } \\
\text { Sach. }\end{array}$ & ++ & ++ & + & + \\
\hline & & $\begin{array}{c}\text { Scolothrips } \\
\text { intermedius } \\
\text { Bagn. }\end{array}$ & ++ & ++ & + & + \\
\hline \multirow{3}{*}{ Coleoptera } & Carabidae & $\begin{array}{c}\text { Calosoma } \\
\text { sycophama }\end{array}$ & ++ & ++ & ++ & ++ \\
\hline & Coccinellidae & $\begin{array}{c}\text { Coccinella } \\
\text { septempunctata } \\
\text { L. }\end{array}$ & ++ & ++ & ++ & ++ \\
\hline & & $\begin{array}{c}\text { Adolia } \\
\text { bipinctata L. }\end{array}$ & ++ & ++ & ++ & ++ \\
\hline \multirow{2}{*}{ Nenuroptera } & \multirow{2}{*}{ Chrysopidae } & $\begin{array}{l}\text { Chrysopa } \\
\text { corned steph }\end{array}$ & + & + & + & + \\
\hline & & $\begin{array}{l}\text { C.septempunc } \\
\text { tata Wesm. }\end{array}$ & + & + & + & + \\
\hline \multirow{4}{*}{ Hymenoptera } & Braconidae & $\begin{array}{c}\text { Bracon } \\
\text { Hebetor Say. }\end{array}$ & + & + & + & + \\
\hline & Aphididae & $\begin{array}{c}\text { Praon dorsall } \\
\text { Hal. } \\
\end{array}$ & + & + & + & + \\
\hline & \multirow{2}{*}{$\begin{array}{l}\text { Trichogramma- } \\
\text { tidae }\end{array}$} & $\begin{array}{l}\text { T.evanescens } \\
\text { West. }\end{array}$ & + & + & + & + \\
\hline & & T.euproctidis & + & + & + & + \\
\hline
\end{tabular}

Note:+ - rare occurrence; ++ - average occurrence; +++ - common occurrence

The obtained studies are similar to the entomocenosis of inter-field cotton and cereal crops (legumes, vegetables, potatoes) [10], and the agrocenosis of weeds growing around the field. However, primary and secondary (potential species) pest species for cotton and wheat in weeds growing around fields and along streams are particularly diverse entomophagous (parasitic, wild spiders, wild caterpillars, lizards, two-winged entomophagous, wild thrips) mainly in these areas. Rainfall in early spring 2017 had a positive impact on weed growth. The development of such plants (especially comfrey) had influenced the expansion of beneficial insects (beetles, wild bees, etc.). The relatively large number of predatory and parasitic entomophages has led to a low number of pests. In some fields, their ratios go up to $1: 10,1: 20$, or even 1:5 (entomophagous:phytophagous), resulting in natural pest control. Pest phytophagous was $40-50 \%$ less than annually. In most areas of the province, no pesticides were applied at all against aphids and thrips, which were sucking pests on cotton grass. Sulfur only in areas where spiders are at risk (OOQ and sulfur powder stabilized sulfur suspension) [13]. In the remaining $80-90 \%$ of the areas, control measures were carried out using biologically entomophagous (goldfish). Seeing the positive ratio between the pest and the entomophagous, it was explained to the farmers that they should carry out mainly biological control measures and recommendations were given. Cotton nightshade was also observed in cotton fields. The reason for this was observed in wild bees and wild spiders, parasitic entomophagous insects, beetles and wild caterpillars, almost every organ in every ball of cotton (flowers, buds). Therefore, in 2016, most farmers were limited to using the biological method. In cotton balls, the ratio between entomophagous and pest was 1:1, 1:5, 1:10. Such a ratio was 
sufficient for the natural management of pests. In the foothills, an increase in locusts and grasshoppers was observed. These were mainly native species, and the abundance of grass has created conditions for them (Figures 1 and 2).

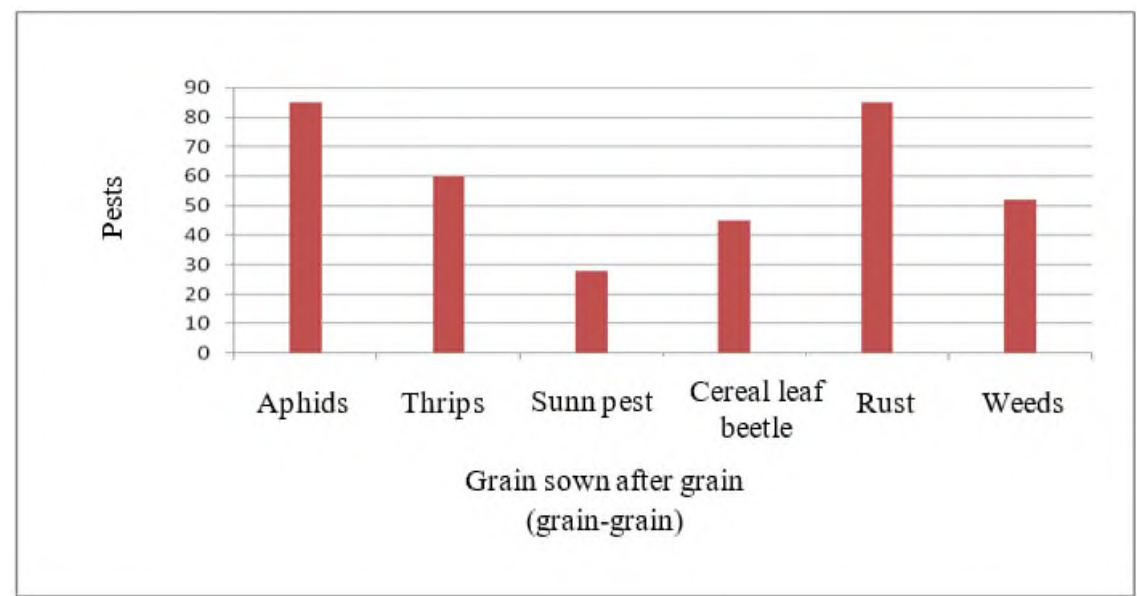

Fig. 1. Changes in the balance of the species composition of pests in the system of crop rotation (Samarkand province, 2015-2017)

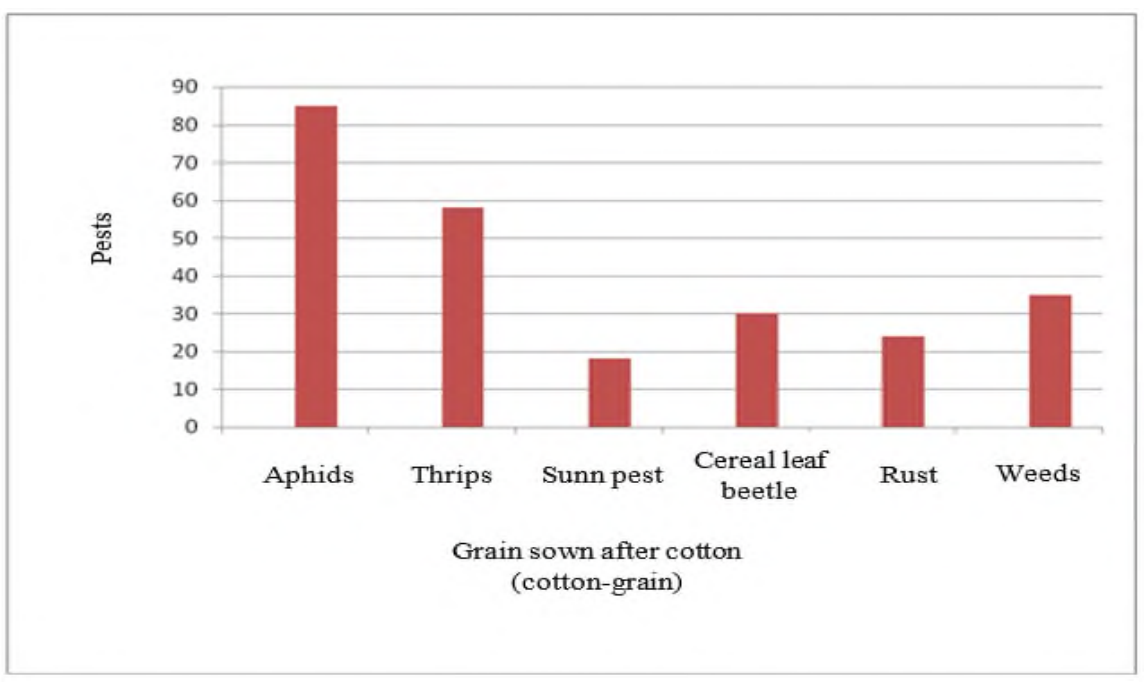

Fig. 2. Changes in the balance of pests in the system of crop rotation (Samarkand province, 2015-2017)

Excessive numbers of beetles in the fields and in weeds, especially in the fields, prevented the pests from growing well, and as a result, most areas were biologically controlled, as there was no need for chemical methods. It was only in early spring that heavy rainfall led to the development of rust disease in grain crops. However, prophylactic treatments were taken to prevent rust disease with Title Duo and other fungicides. The use of stimulants also played an important role in preventing the development of pests. Currently, stimulants (UzGUMI, GUMI, etc.) were used in large areas in all cotton and grain growing districts of Samarkand province. Acceleration of the development of cotton and grain crops under the influence of stimulants greatly contributed to the reduction of the impact of pests and diseases. 
Studies in 2015-2017 found that the relationship between phytophagous and entomophagous in cotton-grain agrophytocenosis can be controlled only by natural methods under conditions that are favorable for beneficial insects (Figures 3 and 4). It was found that the rotation system of "cotton-grain" leads to a natural reduction of grain pests. Especially in the fields where grain was planted after cotton, the incidence of rust disease was 2-3 times lower, and weed infestation was 3-4 times lower, and there was a sharp decrease in spider mites and some wilting diseases in cotton planted after grain [10].

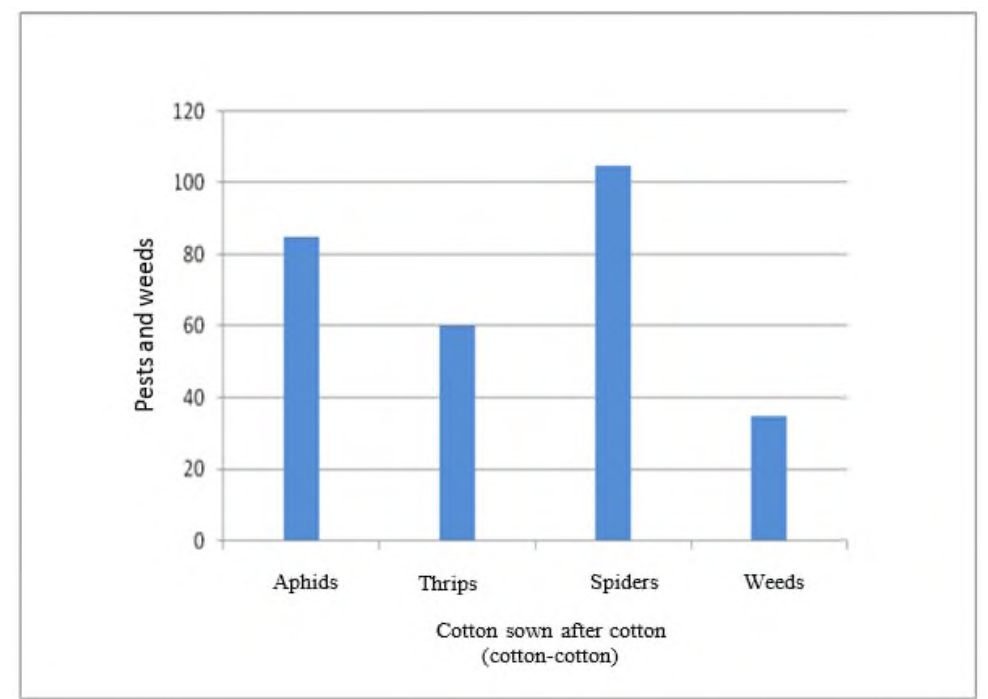

Fig. 3. Changes in the balance of entomofauna in the system of crop rotation (Samarkand province, 2015-2017)

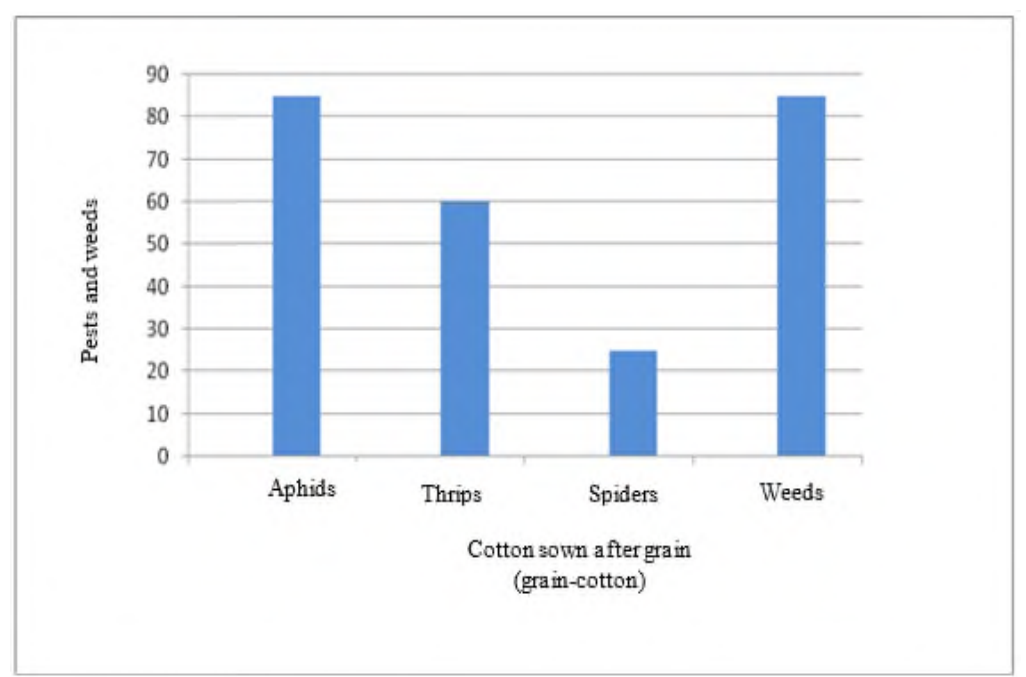

Fig. 4. Changes in the balance of entomofauna in post-grain cotton (Samarkand province, 2015)

Overall, it was found that the use of the "Cotton-grain" crop rotation system naturally reduced the damage of these crops by some pests (cotton diseases, spiders, grain rust and weeds) to 2-4 times. Of course, this allowed to significantly reduce unnecessary cost 
environmental pollution. Reducing the use of pesticides to decrease the transfer of pests from their breeding grounds to crops during the germination period outside the cultivated plots; the use of drugs for low-toxic selective entomophagous at safer times was achieved by enhancing their activity by preserving them. Protecting cotton from pests is a complex and arduous process. It is desirable that all work in this direction be carried out on the basis of modern requirements, economically and environmentally sound.

In recent years, there have been some problems in protecting cotton from pests. In particular, aphids (cotton lice), tobacco thrips and spiders cause significant damage to cotton. Insects spread to the fields during the period when the cotton produces 2-3 leaves, causing the development of seedlings to be delayed by 10-15 days. If timely protective measures were not taken, $30-60 \%$ of crops would be lost due to these pests, and fiber, and seed quality would be impaired. The technology of preventive treatment of cotton was studied in order to improve the protection of cotton from sucking pests in accordance with modern requirements, to find cost-effective ways to harm harmful insects. This technology is an integral part of the integrated plant protection system, which is widely used in world practice. This method protects the weeds around the cotton field and the edges of the field from pests up to 30 meters (from the side of the road). This prevents pests from entering from the edge of the field [12].

Scientific experiments and observations conducted on cotton fields in Akdarya and other districts of Samarkand province showed that there were the advantages of the abovementioned protective technology. It was found that in the fields where such protection technology was used, the number of cotton-sucking pests was 2-3 times less, and the biophonic was preserved. Good growth and development of cotton seedlings was observed. The reason for this was the planting of seeds treated with insecticide up to 30 meters wide, or rows treated with chemicals that serve as a barrier to the passage of plant lice to the edge of the field. It was identified that beneficial insects survived in such fields influenced the effectiveness of biological control methods used, and the cost of protection was reduced by 2-3 times. In fields, where there was a risk of spider mites, the problem was sulfur drugs until the cotton mowing stage $[9-11,13]$, and it was treated by cultivating 30 -meter-wide rows at the edge of the field with one of the special acaricides that are harmless to beneficial insects. In such fields, spider infestation of cotton was found to be reduced by $75-80 \%$ (Table 2).

Table 2. The balance between cousin and pest in conditions where cotton is sucked by pests in different ways (Samarkand province, Pastdargam district 2017-2018)

\begin{tabular}{|c|c|c|c|c|c|c|c|}
\hline \multirow[t]{2}{*}{$\mathbf{N}_{\mathrm{f}}$} & \multirow[t]{2}{*}{ Variants } & \multicolumn{2}{|c|}{ Aphids (cotton lice) } & \multicolumn{2}{|c|}{ Tobacco thrips } & \multicolumn{2}{|c|}{$\begin{array}{c}\text { Spider (red spider } \\
\text { mite) }\end{array}$} \\
\hline & & $\begin{array}{l}\text { Damaged } \\
\text { plants, \% }\end{array}$ & $\begin{array}{c}\text { Number } \\
\text { of pests } \\
\text { per } 1 \\
\text { insect }\end{array}$ & $\begin{array}{l}\text { Damaged } \\
\text { plants, \% }\end{array}$ & $\begin{array}{c}\text { Number } \\
\text { of pests } \\
\text { per } 1 \\
\text { insect }\end{array}$ & $\begin{array}{c}\text { Damaged } \\
\text { plants, } \\
\%\end{array}$ & $\begin{array}{c}\text { Number } \\
\text { of pests } \\
\text { per } 1 \\
\text { insect }\end{array}$ \\
\hline 1 & $\begin{array}{c}\text { Untreated } \\
\text { field (control) }\end{array}$ & 93.1 & $1: 296$ & 92.4 & $1: 126$ & 36.3 & $1: 189$ \\
\hline 2 & $\begin{array}{c}\text { A chemically } \\
\text { biologically } \\
\text { treated field } \\
30 \\
\text { meters wide } \\
\text { from the edge } \\
\text { of the field }\end{array}$ & $\begin{array}{l}62.6 \\
60.4\end{array}$ & $\begin{array}{l}1: 43.6 \\
1: 89.1\end{array}$ & $\begin{array}{l}48.0 \\
68.3\end{array}$ & $\begin{array}{l}1: 29.0 \\
1: 47.3\end{array}$ & $\begin{array}{l}30.9 \\
29.1\end{array}$ & $\begin{array}{l}1: 46.0 \\
1: 80.4\end{array}$ \\
\hline
\end{tabular}




\section{Conclusion}

In short, in order to naturally control (reduce or eliminate) the number of harmful organisms (pests, diseases and weeds) in the agrophytocenosis, it was necessary to properly organize the system of crop rotation "Cotton-grain. Diseases (especially aphids), weeds (especially oats, raygras, etc.), pests (weeds, wheat thrips, slugs, etc.) were 2-3 times less in the grain planted after cotton, the number of spiders in the cotton field planted after grain were 3-4 times less, and disease was decreased by 25-30\%. Monoculture should be avoided, as in recent years weeds have been increasing sharply, especially in grain fields. In protecting cotton from sucking pests, work with predicted field weeds and effective insecticides allowed in rows up to $30 \mathrm{~m}$ wide from the edge of the field to reduce the damage of sucking pests to cotton, prevent their spread, and increase the effectiveness of biological and chemical protection against large areas, and allows to reduce costs.

\section{References}

1. H. M. Yesuf, Q. Xiaohong, A. K. Jhatial, Cotton Science and Processing Technology, $11(2020)$

2. A. Tanveer, R. M. Ikram, H. H. Ali, Agronomic Crops, 15-18 (2019)

3. V. T. Alyokhin, Protection and quarantine of plants 8, 10 (2014)

4. D. R. Bottrell, D. G. Bottrell, Council on Environmental Quality, 1124-1129 (1979)

5. C. Carlo, Potato. I. 35, 3-4 (2008)

6. R. G. Luttrell, Annual review of entomology 39, 1 (1994)

7. C. A. Midega, Crop Protection 42, 9 (2012)

8. B.S. Boltaev, B. M. Abzalova. M. Makhmudova, Bayserke-agro, 141 (2019)

9. B. S. Boltaev, the American Journal of Agriculture and Boimedical Engineering 2, 8 (2020)

10. B. S. Boltaev, Navryz press, Tashkent, Uzbekistan, 24 (2020)

11. B. S. Boltaev, D. D. Akhanov, D. U. Orynbekova, Proceedings of the scientific conference dedicated to the 25th anniversary of Independence of the Republic of Kazakhstan Kazakhtan, 89-95 (2016)

12. Zh. K. Musayeva, Scientific and practical research 7, 3 (2019)

13. R. Ochilov, Protection and quarantine of plants, 9 (2009)

14. N. V. Parahin, N. Lysenko, Bulletin of Agrarian Science 39, 6 (2012) 